\title{
Original
}

\section{Bioremediation of Bisphenol-A Polluted Soil by Sphingomonas bisphenolicum AO1 and the Microbial Community Existing in the Soil}

\author{
YOSHINOBU MATSUMURA ${ }^{1,2 *}$, AYAKO AKAHIRA-MORIYA', \\ AND MIHO SASAKI-MORI ${ }^{1}$ \\ Department of Life Science and Biotechnology, Kansai University, \\ 3-3-35 Yamate-cho, Suita, Osaka 564-8680, Japan \\ ${ }^{2}$ Organization for Research and Development of Innovative Science and Technology, Kansai University, \\ 3-3-35 Yamate-cho, Suita, Osaka 564-8680, Japan
}

Received 15 July, 2014/Accepted 18 September, 2014

\begin{abstract}
Bisphenol A (BPA, 2,2'-Bis (4-hydroxyphenyl) propane) is an artificial pollutant that is easily detected in soil and water environments. BPA decomposition and removal from the environment is relatively difficult due to its stability. This study evaluated the BPA decomposition and removal activities of the microbial community existing in the soil with or without Sphingomonas bisphenolicum AO1, and revealed the toxic effects of BPA towards the microbial community. The microbial community in soil was able to degrade BPA at $1.0 \mathrm{mg} \cdot \mathrm{g}^{-1}$ soil or lower, although its degradation was slow. On the other hand, BPA at more than $10 \mathrm{mg} \cdot \mathrm{g}^{-1}$ soil was not only degraded by the microbial community but also decreased its diversity, suggesting that BPA is harmful to many microorganisms. PCR-TTGE analysis and the cloned 16S rRNA gene sequence analysis indicated that Sphingomonadales, Xanthomonadales, Burkholderiales and Pseudomonadales in the microbial community might independently or cooperatively degrade BPA. On the other hand, supplementation with strain AO1 was able to significantly improve the BPA decomposition activity of the microbial community in soil even at $10 \mathrm{mg} B P A \cdot \mathrm{g}^{-1} \mathrm{soil}$, although BPA at $100 \mathrm{mg} \cdot \mathrm{g}^{-1}$ soil overwhelmed the BPA decomposition activity of strain A01. Furthermore, it was also concluded that strain AO1 could not inhabit BPA purified soil after decomposition of BPA by strain AO1 and the soil microbial community, suggesting that the application of strain AO1 could be a low-burden method for the decomposition and removal of BPA from the natural environment.
\end{abstract}

Key words : Bisphenol A / Xenobiotic pollution / Bioremediation / PCR-TTGE analysis / Sphingomonas.

\section{INTRODUCTION}

Bisphenol A (BPA, 2,2'-bis (4-hydroxyphenyl) propane) is one of the raw materials used in the production of polycarbonate and epoxy resin, and is regarded as an environmental pollutant that is easily detectable in soil and aquatic environments, including ground water and leachate from waste landfill sites (Kang et al., 2006a). Mohapatra et al. (2010) also reported that wastewater from BPA producing,

*Corresponding author. Tel: +81-6-6368-0934, Fax: +81-66388-8609, E-mail: ymatsu(a)kansai-u.ac.jp processing and manufacturing facilities, including paper industries, was contaminated with BPA at relatively higher concentrations than other environments. Muncke (2009) also suggested that humans are usually exposed to BPA and its derivatives through ingestion of food and beverages that are packaged in cans, bottles, and containers made with polycarbonate plastics and epoxy resins in consideration of the BPA contamination observed in food simulants and foodstuffs (Kang and Kondo, 2002; Munguia-Lopez and Soto-Valdez, 2001; Simal-Gandara et al., 1993; Simoneau et al., 1999).

The estrogen activity of BPA has been reported to be $10^{-3}$ to $10^{-5}$ times lower than that of natural estrogen, 
17ß-estradiol, suggesting that the risk of BPA affecting human health is extremely low (Gaido et al., 2001; Markey et al., 2001). On the other hand, Welshons et al. (1999) reported that, with low doses of BPA (2-20 $\mu \mathrm{g} / \mathrm{kg}$ body in adult mice), there were adverse effects on the reproduction and the development of mammalian cells and estrogen activity could be observed, whereas BPA at high doses leds to acute cytotoxicity. However, Tyl et al. (2008) reported that, with low doses of BPA, no selective reproductive or developmental effects were exhibited, compared with slight systemic effects at high doses in adult CD-1 mice.

Even though these conflicting observations on toxicity were reported at low doses of BPA, many researchers have confirmed the toxicity of BPA at high doses. In particular, BPA exposure led to the increased height of luminal epithelial cells in the uterus and induction of lactoferrin in CD-1 mice (Markey et al., 2001). Recently, it has also been reported that BPA affects the dopamine system, including dopamine synthesis, release, uptake and receptor activation, and is considered an environmental neurotoxicant (Jones and Miller, 2008). Stahlhut et al. (2009) reported an epidemiological study of humans and demonstrated that complete clearance of BPA from the body was very slow, suggesting that substantial BPA exposure could lead to significant accumulation in body tissues, such as fat. BPA can affect reproduction and development in invertebrates (Crain et al., 2007; Oehlmann et al., 2009) and leads to acute toxicity in aquatic plants at relatively high concentrations (Alexander et al, 1988; Mihaich et al., 2009). These reports indicate that BPA accumulation in the environment might be markedly toxic to many organisms. However, little information is available regarding BPA toxicity in microorganisms.

To date, many microbiological researchers have focused on the degradation and transformation of BPA by microorganisms and isolated BPA degrading microorganisms (Staples et al., 1998; Mohapatra et al., 2010; Kand et al., 2006). In many cases, these researchers focused on water environments and the BPA degradation capacities of isolated microorganisms in liquid culture. In our laboratory, BPA degradable bacteria, Sphingomonas bisphenolicum strain $\mathrm{AO} 1$ and others, were isolated from soil environments in Japan, and its BPA degradation activities in liquid culture were characterized (Sasaki et al., 2005; Matsumura et al., 2009).

In this study, we evaluated the BPA decomposition activity of microbial communities in the soil and the effect of supplementation with strain AO1. Furthermore, we observed that the growth of Sphingomonas bisphenolicum strain AO1L, a spontaneously isolated non-BPA degrading mutant from strain $\mathrm{AO}$, was markedly inhib- ited by the addition of BPA to the liquid culture (Sasaki et al., 2008). It was also confirmed BPA was harmful to the microbial communities in the soil.

\section{MATERIALS AND METHODS}

\section{Soil sample}

The soil sample was collected from the kitchen garden in Yawata city, Kyoto Prefecture, where some flowers and vegetables had been planted throughout the year. The soil sample was passed through a sieve (approximately $2 \times 2 \mathrm{~mm}$, grid pore) to remove stones, plants, bugs and litter, and stored at $-80^{\circ} \mathrm{C}$ until used. When necessary, the cleaned soil was sterilized by autoclaving at $121^{\circ} \mathrm{C}$ for $30 \mathrm{~min}$, and sterile MilliQ water was added to adjust the soil to the appropriate waterholding capacity.

Water-holding capacity in the soil sample was defined and measured by the following method. After the cleaned soil was weighed, with or without being dried at $100^{\circ} \mathrm{C}$ for 5 hours, $50 \mathrm{~g}$ of the dried soil was mixed well with $50 \mathrm{ml}$ of MilliQ water. Excess water was collected by filtration, and the removed water volume was measured. The maximum water content in the soil, defined as $100 \%$ water-holding capacity, was calculated by subtraction of the removed water content from the $50 \mathrm{ml}$ of added water. The maximum water-holding content of $100 \mathrm{~g}$ of soil used in this study was $82 \mathrm{ml}$. The water content of the cleaned soil was calculated by subtraction of the weight of the cleaned wet soil from that of the dry soil.

\section{Bacterial strains, vectors and cultivation in medium}

Previously isolated S. bisphenolicum AO1 (Sasaki et al., 2005) was used as a BPA degrader and cultivated in $L$ medium and BPA-polluted soil at $30^{\circ} \mathrm{C}$. Escherichia coli strains TOP10 ( $\mathrm{F}^{-}$, mcrA, $\triangle$ (mrr-hsdRMS-mcrBC), \$80lacZ $\triangle M 15, \triangle$ lacX74, nupG, recA1, araD139, $\triangle$ (ara-leu) 7697, galE15, galK16, rpsL (Str ${ }^{\mathrm{R}}$ ), endA1) and JM109 (endA1, glnV44, thi-1, relA1, gyrA96, recA1, mcrB $^{+} \triangle\left(\right.$ lac-proAB) e14 $\left[\mathrm{F}^{\prime}\right.$ traD36 proAB ${ }^{+}$ lacla lacZ $\triangle M 15]$ hsdR17 $\left.\left(r_{\mathrm{K}}{ }^{-} \mathrm{m}_{\mathrm{K}}{ }^{+}\right)\right)$were used as host strains for molecular cloning of the DNA fragments. pGEM-T Easy vector, purchased from Promega Co. (Madison, WI), was used as a vector. E. coli strains were cultivated at $37^{\circ} \mathrm{C}$ in $\mathrm{L}$ medium. In an agar plate, $1.5 \%$ agar was mixed in medium. E. coli recombinants were cultivated in $L$ medium containing $100 \mathrm{mg} \cdot \mathrm{L}^{-1}$ of sodium ampicillin.

\section{Cultivation of bacteria and BPA degradation in soil}

Sterile water was added to $80 \mathrm{~g}$ (dry weight) of soil, and water-holding soil samples at $60 \%$ or $100 \%$ capacity were prepared in a sterile $300 \mathrm{ml}$ Erlenmeyer 
flask capped with a Silicosen (Shin-Etsu Polymer Co.). BPA powder that had been ground with a mortar and pestle was mixed into the soil samples at $0.1,1.0,10$ and $100 \mathrm{mg} \mathrm{BPA} \cdot \mathrm{g}^{-1}$ of dry soil. Strain AO1 cells were prepared by cultivation at $30^{\circ} \mathrm{C}$ in $\mathrm{L}$ medium until the mid-log growth phase and washing twice with sterile water. The resultant cells were suspended in sterile water and were inoculated the BPA-containing soil samples at $1.0 \times 10^{7}$ cells $\cdot g^{-1}$ of dry soil. Soil samples were incubated at $30^{\circ} \mathrm{C}$ at $120 \mathrm{rpm}$ in a rotary shaker. Evaporation of water from the incubated soil samples during cultivation was estimated daily from the changes in mass and sterile water was added to maintain the water holding capacity.

\section{BPA extraction from soil and its quantitative analysis}

A portion of the cultured soil was collected into a 1.5 $\mathrm{ml}$ sampling tube and dried at $50^{\circ} \mathrm{C}$ overnight in a drying oven (DO-450, luchi Co., Osaka, Japan). An aliquot $(0.5 \mathrm{~g})$ of the dried soil was mixed vigorously with 600 $\mu \mathrm{l}$ of ethyl acetate for $10 \mathrm{~min}$. After centrifugation at $9200 \mathrm{~g}$ at $4^{\circ} \mathrm{C}$ for $5 \mathrm{~min}, 200 \mu \mathrm{l}$ of the ethyl acetate layer was recovered. The remaining debris was supplemented with another $300 \mu \mathrm{l}$ of ethyl acetate and mixed vigorously for $10 \mathrm{~min}$. After centrifugation, as described above, $300 \mu \mathrm{l}$ of the ethyl acetate layer was recovered. After two additional washes, $1.1 \mathrm{ml}$ of the recovered ethyl-acetate fraction was dried at $60^{\circ} \mathrm{C}$ in a centrifugal evaporator (CVE-2000, Tokyo Rika Co., Tokyo, Japan), and the remaining debris was dissolved in $5 \mu$ of ethyl acetate and $500 \mu \mathrm{l}$ of $20 \%$ acetonitrile.

The BPA concentration in the $20 \%$ acetonitrile solution was measured with a LaChrom 7000 HPLC system (Hitachi) on a TSKgel superODS column (pore size 2.3 $\mu \mathrm{m}$, column size $4.6 \mathrm{~mm}$ ID $\times 10 \mathrm{~cm}$, $\mathrm{TOSOH} \mathrm{Co}$, Tokyo, Japan). The analytical conditions have been described previously (Sasaki et al., 2008).

\section{DNA extraction from bacteria in soil culture}

DNA was extracted from bacteria in the soil using the hot-detergent method described by Kuske et al. (1998) and Jackson et al. (1997). An aliquot $(0.5 \mathrm{~g})$ of soil was mixed with $2 \times$ TENS buffer (comprised of $100 \mathrm{mM}$ Tris- $\mathrm{HCl}$ (pH8.0), $40 \mathrm{mM}$ EDTA.2Na, $200 \mathrm{mM} \mathrm{NaCl}$ and $2 \%$ SDS), and incubated at $70^{\circ} \mathrm{C}$ for 20 min with an occasional vigorous mixing to lyse the cells and dissolve the bacterial DNA. After centrifugation at 9,200 $g$ at room temperature for 5 min, the resultant supernatant was recovered. DNA in the supernatant was isolated using the ethanol precipitation method and re-suspended in $100 \mu \mathrm{l}$ of TE buffer $(10 \mathrm{mM}$ Tris- $\mathrm{HCl}$ pH8.0 and 1mM EDTA.2Na). Humic acids contaminated in the DNA suspension were purified with a Sepharose 4B spin column (Sigma-Aldrich Co., St.
Louis MO).

\section{Gene cloning, DNA manipulation and phylogenetic analysis}

Molecular phylogenetic analysis of the bacterial community in the soil was performed using the DNA structures of the 16S rRNA gene and their nucleotidesequences. The $\mathrm{V} 3-\mathrm{V} 5$ region of the bacterial $16 \mathrm{~S}$ rRNA gene was amplified using the following PCR method with a GC-clamped-357f primer [5'-GCclampCCTACGGGAGGCAGCA-3'] and 907r primer [5'CCGTCAATTCCTTTGAGTTT-3'] (Marchesi et al., 1998). The GC-clamp sequence [5'-CGCCCGGGGCG CGCCCCGGGCGGGGCGGGGGCACGGGGGG-3'] was according to the report described by $Y u$ and Morrison (2004). The composition of the PCR reaction solution was $2.5 \mathrm{U}$ of Taq DNA polymerase (Thermo Fisher Scientific Inc., Waltham MA), in the appropriate reaction buffer for the polymerase, $5 \mathrm{ng}$ of template DNA, 5 pmoles of each primer, $0.2 \mathrm{mM}$ dNTP and $5 \mu \mathrm{g}$ of BSA in a $50-\mu$ reaction solution. The PCR conditions were as follows: one cycle of $96^{\circ} \mathrm{C}$ for $5 \mathrm{~min}, 35$ cycles of $96^{\circ} \mathrm{C}$ for $45 \mathrm{sec}, 51^{\circ} \mathrm{C}$ for $45 \mathrm{sec}$ and $72^{\circ} \mathrm{C}$ for $50 \mathrm{sec}$, and final one cycle of $72^{\circ} \mathrm{C}$ for $5 \mathrm{~min}$.

Amplified DNA fragments were confirmed by conventional agarose gel electrophoresis with a Mupid a system and temperature gradient gel electrophoresis (TGGE) with a DCode system (Bio-rad). In TGGE, an $8 \%$ acrylamide gel containing $8 \mathrm{M}$ urea and 1XTAE (40 $\mathrm{mM}$ Tris base, $20 \mathrm{mM}$ acetic acid, and $1 \mathrm{mM}$ EDTA) was used, under electrophoresis conditions ( $50 \mathrm{~V}$ for $17 \mathrm{~h}$ ), with a temperature gradient of $0.6^{\circ} \mathrm{C}$ per $\mathrm{h}$, from $60^{\circ} \mathrm{C}$ to $70^{\circ} \mathrm{C}$. DNA fragments were stained with a SYBR gold nucleic acid gel stain system (Life Technologies Co., Carlsbad CA) or a silver stain II kit (Wako Pure Chemical Industries, Osaka Japan). The gel image was captured with a DC290 zoom digital camera (Eastman Kodak Co., Rochester NY).

In FIG.4, the amplified DNA fragment was extracted from the acrylamide gel after incubation in TE buffer at $4^{\circ} \mathrm{C}$ overnight. The extracted DNA fragment was cloned with a pGEN-T easy vector system (Promega). The plasmid in the E. coli was purified with a Wizard plus SV miniprep DNA purification system (Promega). The nucleotide sequence of the DNA fragment was determined with an ABI PRISM3100 genetic analyzer (Life Technologies) and phylogenetic analysis was performed with MacVector software (MacVector, Inc., Cary NC) including the Blast program. In FIG.5, the amplified DNA fragment was confirmed with a conventional agarosegel electrophoresis, and with a Qiaexll gel extraction kit (Qiagen N. V., Venlo, Netherlands). The extracted DNA fragment was cloned into a pGEN-T easy vector system and sequenced. 


\section{Chemicals}

Chemicals were purchased from Wako Pure Chemical Industries and Kanto Chemical Co. (Tokyo Japan), except where described above. Culture media was purchased from Becton, Dickinson and Company (Sparks MD). Chemicals for molecular biology, i.e., restriction enzymes and ligase, were purchased from Takara Bio Inc. (Otsu Japan) and Toyobo Co. (Osaka Japan).

\section{RESULTS AND DISCUSSION}

\section{BPA pollution in soil is mitigated by soil inhabiting microorganisms}

BPA contamination and the existence of BPA degrading bacteria have been frequently reported in aquatic environments and the BPA degradation activities of these bacteria have been evaluated in liquid culture (Kang et al., 2006b). However, there have been some suggestions that these bacteria could decompose and metabolize water-insoluble BPA in soil, even though BPA exhibits low water solubility. Therefore, this study explored the fate of BPA contamination in soils containing existing microorganism communities, with or without strain AO1. We also explored the adverse or toxic effects of BPA on microorganisms in soil.

BPA-contaminated soil at $60 \%$ water holding capacity was incubated at $30^{\circ} \mathrm{C}$ with shaking. Soil was initially contaminated with powdered BPA at 0.1, 1.0 and $10 \mathrm{mg} \mathrm{BPA} \cdot \mathrm{g}^{-1}$ of dry soil. The BPA degrading capacity and BPA transformation by microbial communities in the soil were measured and monitored with HPLC (closed squares and dotted lines in FIG.1). Initially, it was confirmed that recovery of BPA from contaminated soil with an ethyl acetate extraction was approximately $10 \%$ to $95 \%$, and that its recovery was significantly more difficult at low concentrations (below $1.0 \mathrm{mg} \cdot \mathrm{g}^{-1}$ soil; see time 0 in FIG. 1a-b), suggesting that a small portion of BPA was trapped in or extremely tightly bound to the soil. It was also confirmed that BPA at more than $5 \mu \mathrm{g} \cdot \mathrm{g}^{-1}$ dry soil was detectable with our BPA measurement method (data not shown).

BPA at $0.1 \mathrm{mg} \cdot \mathrm{g}^{-1}$ dry soil was quickly degraded to below $0.01 \mathrm{mg} \cdot \mathrm{g}^{-1}$ after 7 days, but, even after 35 days of cultivation, BPA could not be completely eliminated, based upon HPLC analysis, suggesting that a small portion of BPA was tightly bound to the soil or was not in contact with the bacteria (FIG.1a dotted line). With BPA contamination at $1.0 \mathrm{mg} \cdot \mathrm{g}^{-1}$, BPA purification below $0.1 \mathrm{mg} \cdot \mathrm{g}^{-1}$ was observed after 14 days (FIG. $1 \mathrm{~b}$ dotted line). These results indicated that at low concentrations, BPA was purified and removed by the native microbial community itself. In contrast, in BPA-contaminated soil at $10 \mathrm{mg} \cdot \mathrm{g}^{-1}$ soil, the native
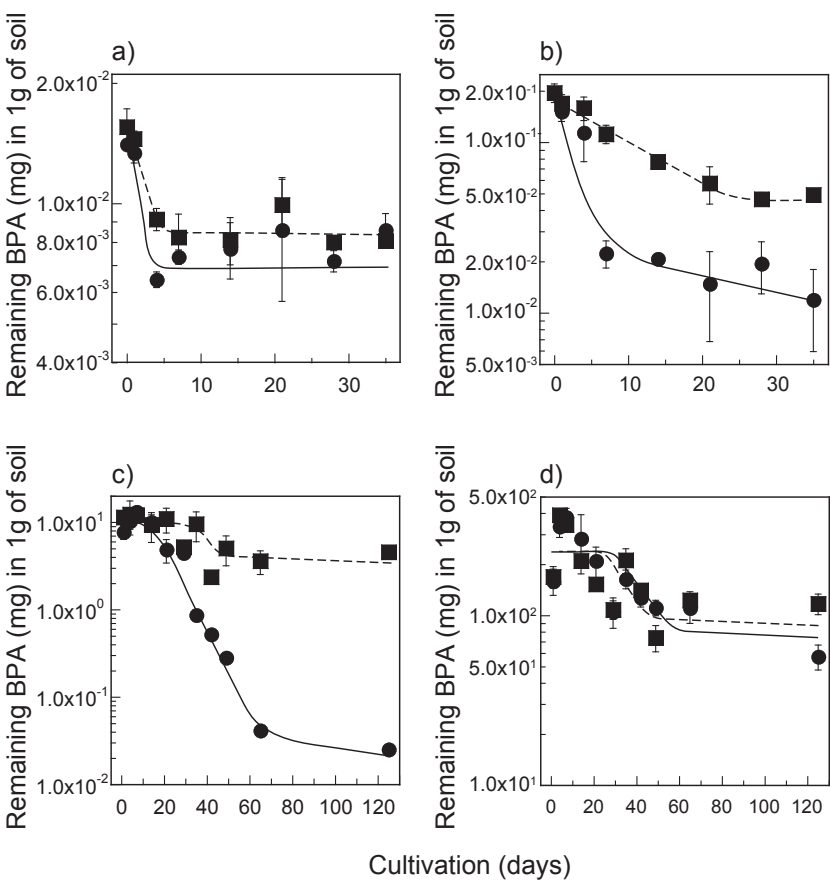

FIG. 1. BPA purification in the BPA contaminated soil by microorganisms naturally inhabiting the soil with or without strain AO1. Soil was contaminated with BPA at 0.1 (a), 1.0 (b), 10 (c) and 100 (d) $\mathrm{mg} \cdot \mathrm{g}^{-1}$ soil. The BPA contaminated soil was incubated at $30^{\circ} \mathrm{C}$ and the water-holding capacity in the soil was maintained at $60 \%$. Closed circles (solid line) and squares (dotted line) indicate the incubated soil with and without strain AO1 inoculation, respectively. Plots and error bars indicate the mean and standard deviation for 3 independent replicates of BPA extractions, respectively.

microbial community only slightly and temporally degraded BPA; approximately 50 days was necessary for approximately 50\% BPA degradation (FIG.1c dotted line). At $100 \mathrm{mg} \mathrm{BPA} \cdot \mathrm{g}^{-1}$ soil, BPA purification and removal by the native microbial community was defective and a large proportion of BPA remained in the soil (FIG.1d dotted line), suggesting that bacteria inhabiting the soil were sensitive to BPA at high concentration and, alternatively, that BPA was toxic to microorganisms. It was also observed that autoclaved soil could not degrade BPA, indicating that the microbial community was necessary for BPA removal and purification from the soil (FIG.2).

\section{Strain A01 accelerated BPA degradation in the soil}

Strain AO1 was isolated as a powerful BPA degrading bacterium and was expected to improve BPA degradation activity in the soil. This hypothesis was confirmed by the following findings (closed circles and solid lines in FIG.1). The contaminated soil at 0.1, 1.0, 10 and 100 $\mathrm{mg} \mathrm{BPA} \cdot \mathrm{g}^{-1}$ soil was inoculated with the viable strain AO1 cells and incubated for 91 days. In soil contami- 


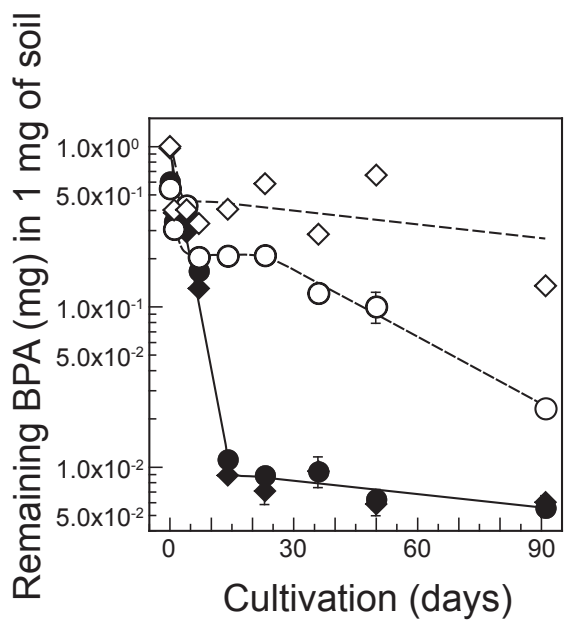

FIG. 2. BPA purification in BPA contaminated soil at 1.0 $\mathrm{mg} \cdot \mathrm{g}^{-1}$ soil with or without microorganisms naturally inhabiting the soil. Autoclaved (diamonds) and non-autoclaved (circles) soil was used in this study. BPA purification was performed with (closed symbols) or without (open symbols) strain A01. The BPA purification conditions were as indicated in FIG. 1. Plots and error bars indicate the mean and standard deviation for 3 independent replicates of BPA extractions, respectively.

nated at $0.1 \mathrm{mg} \mathrm{BPA} \cdot \mathrm{g}^{-1}$ of soil, initial BPA degradation for 5 days was improved slightly by supplementation with strain $\mathrm{AO1}$, and its remarkable improvement by strain AO1 could not be kept in the additional cultivation. On the other hand, BPA degradation and purification in the soil contaminated with 1.0 to $10 \mathrm{mg} \mathrm{BPA} \cdot \mathrm{g}^{-1}$ soil was accelerated by strain $\mathrm{AO1}$, although this was not effective at $100 \mathrm{mg} \mathrm{BPA} \cdot \mathrm{g}^{-1}$ soil. Furthermore, BPA removal and degradation was highly effective: approximately $99 \%$ in the BPA contaminated soil at 1.0 and 10 $\mathrm{mg} \cdot \mathrm{g}^{-1}$ of soil for 20 and 60 days, respectively.

Similar to the experiments demonstrating BPA removal by the soil microbial community in the absence of strain AO1, described above, the soil containing strain AO1 could not completely degrade BPA, and a small proportion of BPA remained in the soil, even when the incubation was prolonged (FIG.1), suggesting that a small proportion of the BPA was strongly bound to soil cavities and could not come into contact with the strain AO1 cells. Our study also revealed that the microbial community existing in the soil could remove BPA from the soil but that this contribution to BPA degradation was extremely low compared with strain AO1, because the synergistic or additive effects of the inhabitants on BPA degradation would not be observed in the soil containing strain $\mathrm{AO}$ ( $\mathrm{FIG} .2$ ).

\section{Microbial flora in the soil is influenced and changed by BPA pollution}

a) Cultivation (days)

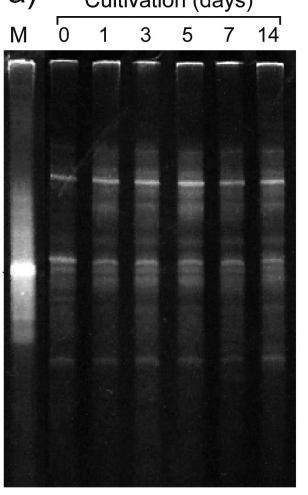

b) Cultivation (days)

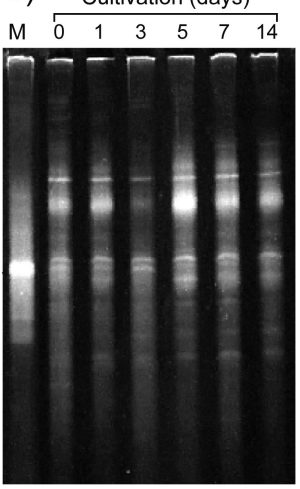

C) Cultivation (days)

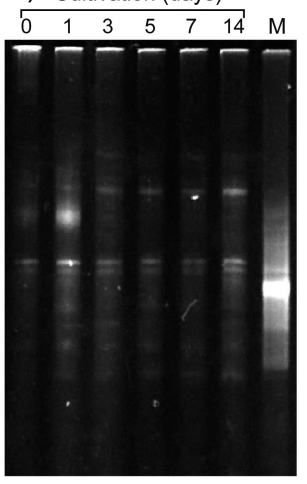

d) Cultivation (days)

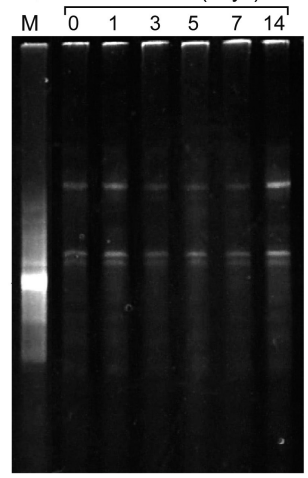

$0.1 \mathrm{mg}$ BPA in $1 \mathrm{~g}$ of soil

+ Strain AO1

FIG. 3. Analysis of bacterial diversity in soil by PCR-TTGE (1). DNA samples were recovered from cultivated soil with (c and d) or without (a and b) BPA at $0.1 \mathrm{mg} / \mathrm{g}$ of soil for 0,1 , $3,5,7$ and 14 days at $30{ }^{\circ} \mathrm{C}$ and at $100 \%$ water-holding capacity. In parts of the experiments (b and $d$ ), soil was inoculated with strain $\mathrm{AO} 1$ at the start of the cultivation (0 day). DNA fragments for this analysis were prepared by PCR, as the described in MATERIALS and METHODS. In lane M, chromosomal DNA from strain AO1 cultivated in LB medium was prepared as a PCR template.

It has been reported that BPA can exhibit several adverse effects in animals, plants and aquatic organisms, in addition to its action as an endocrine disruptor (Flint et al., 2012; Staples et al., 2002; Mihaicha et al., 2009). However, little information is available regarding its effect(s) against microorganisms. In our previous study, the growth of strain AO1L, a non-BPA degrading mutant, was markedly inhibited by BPA, strongly suggesting that BPA would be harmful to many bacteria (Matsumura et al, 2009). Therefore, we evaluated the adverse effects of BPA on the microbial flora in soil using the PCR-TTGE method.

As described above, BPA at high concentrations in soil, $\geq 10 \mathrm{mg} \mathrm{BPA} \cdot \mathrm{g}^{-1}$ soil, could not be significantly removed or metabolized by bacteria naturally inhabiting the soil, and BPA at $100 \mathrm{mg} \cdot \mathrm{g}^{-1}$ soil could not be eliminated, even by strain A01. Indeed, the PCR-TTGE 


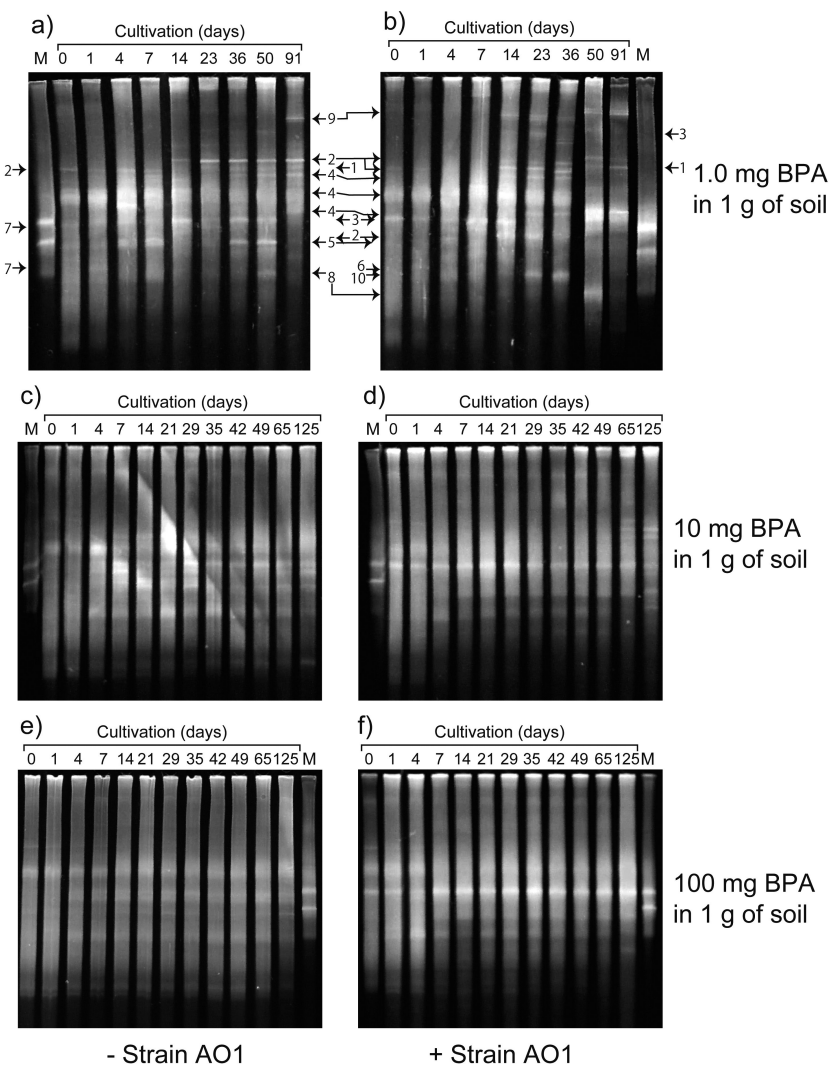

FIG. 4. Analysis of bacterial diversity in soil by PCR-TTGE (2). DNA samples were recovered from soil cultivated with BPA at $1.0 \mathrm{mg}$ ( $\mathrm{a}$ and b), $10 \mathrm{mg}$ ( $\mathrm{c}$ and d) and $100 \mathrm{mg}$ (e and $\mathrm{f}$ ) in $1 \mathrm{~g}$ of soil for the indicated number of days at $30^{\circ} \mathrm{C}$ and water-holding capacity of 60\% (see FIG. 1b-d). In parts of experiments ( $b, d$ and $f$ ), soil was inoculated with strain AO1 at the start of the cultivation (0 day). DNA samples were prepared by PCR, as described in MATERIALS and METHODS. In a) and b), 16S rRNA gene fragments that were visualized on the gel were then cloned and classified; (1) Caulobacterales, (2) Sphingomonadales, (3) Burkholderiales, (4) Pseudomonadales, (5) Xanthomonadales, (6) Enterobacteriaceae, (7) Acidobacteriacea, (8) Paenibacillaceae, (9) Bacillus sp., (10) Actinobacteria. In lane M, chromosomal DNA from strain AO1 cultivated in LB medium was prepared as a PCR template.

analyses (FIG.3-4) demonstrated that microbial flora with or without strain AO1 dynamically fluctuated in the moderately BPA polluted soil $\left(1.0 \mathrm{mg} \cdot \mathrm{g}^{-1}\right.$ soil) during purification of BPA by the microbial flora (FIG.4a-b and FIG.1b). However, in the highly polluted soil, $100 \mathrm{mg}$ $\mathrm{BPA} \cdot \mathrm{g}^{-1}$ soil, the BPA degrading activity of the microbial community was limited, with or without strain $\mathrm{AO1}$, and its flora exhibited less variability (FIGs.4e-f and 1d). In $10 \mathrm{mg} \cdot \mathrm{g}^{-1}$ BPA polluted soil, there was little fluctuation in and little contribution to BPA purification by the native microbial flora (FIGs.4c-d and 1c), although strain AO1

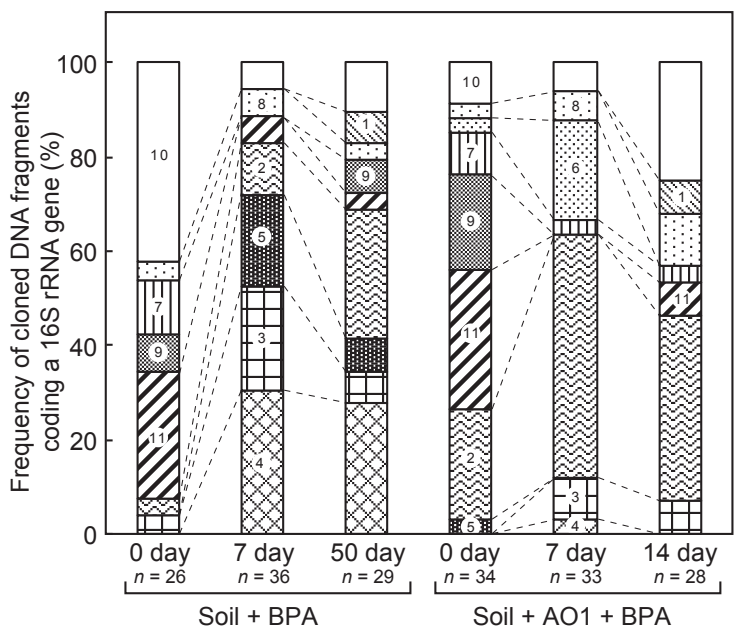

FIG. 5. Transition of detectable bacteria cultivated in the BPA polluted soil at $1.0 \mathrm{mg} \cdot \mathrm{g}^{-1}$ soil with or without strain $\mathrm{AO} 1$ (see FIGs. 1b and 4ab). The DNA samples from the PCR template were prepared from the soil culture at the indicated days. The amplified DNA fragments were cloned into a pGEM-T-Easy vector and sequenced. Bacterial categories were determined from the 16S rRNA gene sequences; (1) Caulobacterales, (2) Sphingomonadales, (3) Burkholderiales, (4) Pseudomonadales, (5) Xanthomonadales, (6) Enterobacteriaceae, (7) Acidobacteria, (8) Rhizobiales, (9) Betapropiobacteria other than Burkholderiales, (10) a set of groups classified into several other orders or families, (11) a set of unclassified bacteria. The number $(n)$ of samples sequenced is indicated below each column.

actively degraded BPA under the same conditions (FIGs.1c and 4d). On the other hand, the microbial flora was not markedly affected in low BPA or non-BPA polluted soils (FIG.3). These results suggested that moderate BPA pollution activated the native microorganism activity to degrade BPA but that high BPA pollution remarkably suppressed their activities and growth.

\section{Classification of bacteria in BPA polluted soil}

Although the PCR-TTGE analyses demonstrated the complexity and sequential fluctuation of the microbial flora, specific information regarding the bacteria was not available. Therefore, DNA fragments were visualized on an agarose gel in PCR-TTGE (FIG.4a-b), extracted and cloned into a pGEM-T-Easy vector. The cloned DNA fragment encoding a 16S rRNA gene was sequenced and classified with the NCBI Blast program and the microbe nucleotide database. In soil culture, 10 types of bacteria were detectable: Caulobacterales and Sphingomonadales in Alphaproteobacteria; Burkholderiales in Betaproteobacteria; Pseudomonadales, Xanthomonadales and Enterobacteriaceae in Gammaproteobacteria; 
Acidobacteriales in Acidobacteria; Paenibacillaceae and Bacillus in Bacillales of Bacilli; and Actinobacteria. These results suggested that many kinds of bacteria were able to cooperatively degrade BPA. It was also suggested that Sphingomonadales, Pseudomonadales and Xanthomonadales were more active during the early stage of cultivation (1 to 14 days), suggesting that these bacteria degraded BPA directly, and that Burkholderiales and many other bacteria were active at the middle stage (after 14 days), suggesting that this type of bacteria might selectively degrade BPAmetabolites.

Although PCR-TTGE analyses revealed most of the bacterial species existing in the culture, the number or proportion belonging to the same species was unclear. Therefore, PCR-amplified DNA fragments, isolated from the BPA polluted soil culture at $1.0 \mathrm{mg} \mathrm{BPA} \cdot \mathrm{g}^{-1}$ soil with or without strain $\mathrm{AO1}$, were directly cloned into a pGEM-T-Easy vector and the cloned fragments $(n=$ 25-35) were sequenced (FIG.5).

Before the cultivation, the predominant bacteria in the soil were Acidobacteria and Betapropiobacteria, and the frequency of Sphingomonadales increased following inoculation with strain $\mathrm{AO} 1$ (see day 0 with or without strain AO1 in FIG.5). It was also confirmed that the bacteria could be classified into several other small groups and that a significant number of unclassified bacteria were detected in the unpolluted soil (see day 0 in FIG.5), compared with BPA polluted soil (see the other columns in FIG.5), suggesting that the microbial diversity in the soil used in this study was rich, but that BPA was harmful to many naturally inhabiting bacteria in this soil.

At the BPA-metabolizing stage (7 days with or without strain AO1 in FIG.5), the frequencies of Sphingomonadales, Xanthomonadales, Burkholderiales and Pseudomonadales increased markedly, consistent with the findings of the PCR-TTGE analyses, suggesting that these bacteria were major players in the degradation of BPA. In the late stage of BPA degradation, or the stage of recovery to the natural environment after complete degradation of BPA (50 days without strain AO1and 14 days with strain AO1; FIG.5), the native bacterial groups that were decreased at day 7 were recovering and newly detectable Caulobacterales were observed. Caulobacterales might only degrade BPA metabolites produced by other bacteria containing strain $\mathrm{AO} 1$.

It was also demonstrated that the presence of strain AO1 suppressed the growth of Xanthomonadales and Pseudomonadales in the BPA polluted soil, while Burkholderiales and Enterobacteriaceae could still grow, suggesting that Burkholderiales and Enterobacteriaceae might support the degradation of BPA by BPA interme- diate metabolites or the enhancement of strain $\mathrm{AO} 1$ growth. It was also suggested that Xanthomonadales and Pseudomonadales in the soil exhibited weaker BPA degrading activity than strain AO1. Indeed, some bacterial strains, belonging to Xanthomonadales, Pseudomonadales, Burkholderiales, Caulobacterales and Enterobacteriaceae, have already been reported as degradative bacterium against aromatic compounds, phenolic compounds or polycyclic aromatic hydrocarbons (Ammar et al., 2005; Chatterjee and Bourquin, 1987; Gutierrez et al., 2013; Haritash and Kaushik, 2009; O'Sullivan and Mahenthiralingam, 2005).

Furthermore, our results indicated that BPA purification by strain $\mathrm{AO} 1$ and the soil bacteria improved or restored the bacterial diversity, for example, Betaproteobacteria, except Burkholderiales, were reduced in BPA polluted soil after 7 days without strain AO1 but were restored at day 50, and unclassified bacteria were also reduced after 7 days in the BPA polluted soil with strain $\mathrm{AO} 1$ but were restored at day 14 (FIG.5). It was also observed that strain $\mathrm{AO} 1$ was only detectable in the BPA polluted soil but not in the purified soil, based upon the Southern hybridization method using the bisdB gene probe (data not shown), which encoded a BPA degradation enzyme in strain AO1 (Sasaki et al., 2008), suggesting that strain AO1 might not lead to a heavy burden in the soil environment. Strain AO1 is expected to be a candidate as a biological cleaner of environmental pollutants.

\section{ACKNOWLEDGEMENTS}

We thank Dr. K. Oshiman at the Sumitomo Forestry Co., Ltd., for valuable and helpful discussions. This study was supported in part by the MEXT-Supported Programs for the Strategic Research Foundation at Private University 2008-2012 and 2013-2018, and JSPS KAKENHI Grant Number 24510108.

\section{REFERENCES}

Alexander, H. C., Dill, D. C., Smith, L. W., Guiney, P. D., and Dorn P. (1988) Bisphenol A: Acute aquatic toxicity. Environ. Toxicol. Chem., 7, 19-26.

Ammar, E., Nasri, M., and Medhioub, K. (2005) Isolation of Enterobacteria able to degrade simple aromatic compounds from the wastewater from olive oil extraction. World J. Microb. Biot., 21, 253-259.

Chatterjee, D. K., and Bourquin, A. W. (1987) Metabolism of aromatic compounds by Caulobacter crescentus. J. Bacteriol., 169, 1993-1996.

Crain, D. A., Eriksen, M., Iguchi, T., Jobling, S., Laufer, H., LeBlanc, G. A., and Guillette, L. J., Jr. (2007) An ecological assessment of bisphenol-A: Evidence from comparative biology. Reprod. Toxicol., 24, 225-239.

Flint, S., Markle, T., Thompson, S., and Wallace, E. (2012) 
Bisphenol A exposure, effects, and policy: A wildlife perspective. J. Environ. Manage., 104, 19-34.

Gaido, K. W., Leonard, L. S., Lovell, S., Gould, J. C., Babai, D., Portier, C. J., and McDonnell, D. P. (1997) Evaluation of chemicals with endocrine modulating activity in a yeastbased steroid hormone receptor gene transcription assay. Toxicol. Appl. Pharm., 143, 205-212.

Gutierrez, T., Green, D. H., Nichols, P. D., Whitman, W. B., Semple, K. T., and Aitken, M. D. (2013) Polycyclovorans algicola gen. nov., sp. nov., an aromatic-hydrocarbondegrading marine bacterium found associated with laboratory cultures of marine phytoplankton. Appl. Environ. Microb., 79, 205-214.

Haritash, A. K., and Kaushik, C. P. (2009) Biodegradation aspects of polycyclic aromatic hydrocarbons (PAHs): a review. J. Hazard. Mater., 169, 1-15.

Jackson, C. R., Harper, J. P., Willoughby, D., Roden, E. E., and Churchill, P. F. (1997) A simple, efficient method for the separation of humic substances and DNA from environmental samples. Appl. Envir. Microb., 63, 4993-4995.

Jones, D. C., and Miller, G. W. (2008) The effects of environmental neurotoxicants on the dopaminergic system: A possible role in drug addiction. Biochem. Pharmacol., 76, 569-581.

Kang, J. H., Katayama, Y., and Kondo, F. (2006a) Biodegradation or metabolism of bisphenol $A$ : from microorganisms to mammals. Toxicology, 217, 81-90.

Kang, J. H., and Kondo, F. (2002) Bisphenol A migration from cans containing coffee and caffeine. Food Addit. Contam., 19, 886-890.

Kang, J. H., Kondo, F., and Katayama, Y. (2006b) Human exposure to bisphenol A. Toxicology, 226, 79-89.

Kuske, C. R., Banton, K. L., Adorada, D. L., Stark, P. C., Hill, K. K., and Jackson, P. J. (1998) Small-Scale DNA Sample Preparation Method for Field PCR Detection of Microbial Cells and Spores in Soil. Appl. Environ. Microb., 64, 2463-2472.

Marchesi, J. R., Sato, T., Weightman, A. J., Martin, T. A., Fry, J. C., Hiom, S. J., Dymock, D., and Wade, W. G. (1998) Design and evaluation of useful bacterium-specific PCR primers that amplify genes coding for bacterial $16 \mathrm{~S}$ rRNA. Appl. Environ. Microb., 64, 795-799.

Markey, C. M., Michaelson, C. L., Veson, E. C., Sonnenschein, C., and Soto, A. M. (2001) The mouse uterotrophic assay: A reevaluation of its validity in assessing the estrogenicity of bisphenol A. Environ. Health Persp., 109, 55-60.

Matsumura, Y., Hosokawa, C., Sasaki-Mori, M., Akahira, A., Fukunaga, K., Ikeuchi, T., Oshiman, K., and Tsuchido, T. (2009) Isolation and characterization of novel bisphenol-Adegrading bacteria from soils. Biocontrol Sci., 14, 161-169.

Mihaich, E. M., Friederich, U., Caspers, N., Hall, A. T., Klecka, G. M., Dimond, S. S., Staples, C. A., Ortego, L. S., and Hentges, S. G. (2009) Acute and chronic toxicity testing of bisphenol A with aquatic invertebrates and plants. Ecotox. Environ. Safe., 72, 1392-1399.

Mohapatra, D. P., Brar, S. K., Tyagi, R. D., and Surampalli, R. Y. (2010) Physico-chemical pre-treatment and biotransformation of wastewater and wastewater sludge - fate of bisphenol A. Chemosphere, 78, 923-941.

Muncke, J. (2009) Exposure to endocrine disrupting compounds via the food chain: Is packaging a relevant source? Sci. Total. Environ., 407, 4549-4559.

Munguia-Lopez, E. M., and Soto-Valdez, H. (2001) Effect of heat processing and storage time on migration of bisphenol A (BPA) and bisphenol A-diglycidyl ether (BADGE) to aqueous food simulant from Mexican can coatings. J. Agr. Food Chem., 49, 3666-3671.

Oehlmann, J., Schulte-Oehlmann, U., Kloas, W., Jagnytsch, O., Lutz, I., Kusk, K.O., Wollenberger, L., Santos, E. M., Paull, G. C., Van Look, K. J., and Tyler, C. R. (2009) A critical analysis of the biological impacts of plasticizers on wildlife. Philos. T. Roy. Soc. B, 364, 2047-2062.

O'Sullivan, L. A., and Mahenthiralingam, E. (2005) Biotechnological potential within the genus Burkholderia. Lett. Appl. Microbiol., 41, 8-11.

Sasaki, M., Maki, J., Oshiman, K., Matsumura, Y., and Tsuchido, T. (2005) Biodegradation of bisphenol A by cells and cell lysate from Sphingomonas sp. strain AO1. Biodegradation, 16, 449-459.

Sasaki, M., Tsuchido, T., and Matsumura, Y. (2008) Molecular cloning and characterization of cytochrome P450 and ferredoxin genes involved in bisphenol A degradation in Sphingomonas bisphenolicum strain AO1. J. Appl. Microbiol., 105, 1158-1169.

Simal-Gandara, J., Lopez-Mahia, P., Paseiro-Losada, P., Simal-Lozano, J., and Paz-Abuin, S. (1993) Overall migration and specific migration of bisphenol A diglycidyl ether monomer and $m$-xylylenediamine hardener from an optimized epoxy-amine formulation into water-based food simulants. Food Addit. Contam., 10, 555-565.

Simoneau, C., Theobald, A., Wiltschko, D., and Anklam, E. (1999) Estimation of intake of bisphenol-A-diglycidyl-ether (BADGE) from canned fish consumption in Europe and migration survey. Food Addit. Contam., 16, 457-463.

Stahlhut, R. W., Welshons, W. V., and Swan, S. H. (2009) Bisphenol A data in NHANES suggest longer than expected half-life, substantial nonfood exposure, or both. Environ. Health Persp., 117, 784-789.

Staples, C. A., Dorn, P. B., Klecka, G. M., O’Block, S. T., and Harris, L. R. (1998) A review of the environmental fate, effects, and exposures of bisphenol A. Chemosphere, 36, 2149-2173.

Staples, C. A., Woodburn, K., Caspers, N., Hall, A. T., and Klecka, G. M. (2002) A weight of evidence approach to the aquatic hazard assessment of bisphenol A. Hum. Ecol. Risk Assess., 8, 1083-1105.

Tyl, R. W., Myers, C. B., Marr, M. C., Sloan, C. S., Castillo, N. P., Veselica, M. M., Seely, J. C., Dimond, S. S., Van Miller, J. P., Shiotsuka, R. N., Beyer, D., Hentges, S. G., and Waechter, J. M., Jr. (2008) Two-generation reproductive toxicity study of dietary bisphenol A in CD-1 (Swiss) mice. Toxicol. Sci., 104, 362-384.

Welshons, W. V., Nagel, S. C., Thayer, K. A., Judy, B. M., and Vom Saal, F. S. (1999) Low-dose bioactivity of xenoestrogens in animals: Fetal exposure to low doses of methoxychlor and other xenoestrogens increases adult prostate size in mice. Toxicol. Ind. Health, 15, 12-25.

Yu, Z., and Morrison, M. (2004) Comparisons of different hypervariable regions of $r$ rs genes for use in fingerprinting of microbial communities by PCR-denaturing gradient gel electrophoresis. Appl. Environ. Microb., 70, 4800-4806. 